\title{
Signal transduction pathways participating in homeostasis and malignant transformation of the intestinal tissue
}

\author{
Minireview $^{* *}$ \\ M. KRAUSOVA, V. KORINEK* \\ Institute of Molecular Genetics, Academy of Sciences of the Czech Republic, Videnska 1083, 14220 Prague 4, Czech Republic \\ ${ }^{\star}$ Correspondence: korinek@img.cas.cz
}

Received April 17, 2012 / Accepted June 18, 2012

\begin{abstract}
Intestinal homeostasis is a complex and tightly regulated process governed by a variety of signalling pathways that balance cell proliferation and differentiation. As revealed by extensive use of defined mouse models, perturbations within the signalling circuitry trigger initial expansion of premalignant cells. In this review, we attempt to summarise recent advances in the knowledge of the cellular signalling mechanisms that drive tumorigenesis in the human and mouse intestine.
\end{abstract}

Key words: colorectal cancer, epithelium, gut, intestine, mouse models, stem cells

Carcinoma of colon and rectum [colorectal cancer (CRC)] represents the third most common human malignancy worldwide. It is estimated that more than one million patients are clinically diagnosed each year; up to one third of the cases constitute metastatic settings resulting in a disease-related mortality rate exceeding 30\% [1]. Development of colorectal neoplasia is characterised by progression through histologically defined stages that include hyperplastic and dysplastic lesions, adenoma and adenocarcinoma [2]. This stepwise evolvement towards more advanced stages is driven by genomic alterations and epigenetic changes. Colorectal cancers are characterised

\footnotetext{
Abbreviations: Ascl2 - achaete-scute complex homolog 2; Apc - adenomatous polyposis coli; $b H L H$ - basic helix-loop-helix; $B M P$ - bone morphogenetic protein; $B R A F$ - v-raf murine sarcoma viral oncogene homolog B1; $C B C$ - crypt base columnar; $C R C$ - colorectal cancer; EphB - ephrin type-B receptor; EGFR - epidermal growth factor receptor; $F z$ - frizzled; Hes - hairy and enhancer of split; Hh - hedgehog; KRAS - v-Ki-ras2 Kirsten rat sarcoma viral oncogene homolog; Lgr5 - leucine-rich-repeat containing G-protein coupled receptor 5; $L k b 1$ - liver kinase B1; $M S I$ - microsatellite instability; NICD - notch intracellular domain; PI3K - phosphatidylinositol 3-kinase; Smo - smoothened
}

by a complex genomic "landscape"; individual tumors harbour nine rearranged loci on average [3] and a median of 76 non-silent mutations [4]. However, only a fraction of these changes is considered to be causative in tumor initiation and progression. For example, several recent studies based on high-throughput sequencing of tumor DNA indicate that only a small portion of mutations are "driver" mutations affecting genes essential for tumor development $[4,5]$. Nevertheless, the contributions of seemingly harmless "passenger" mutations should not be underestimated as these can substantially underpin the known tumorigenic pathways [6].

The single-layer epithelia of the small intestine and colon represent the most rapidly self-renewing adult tissue that completely regenerates approximately every five days $[7,8]$. The long-lived stem cells located at the bottom positions of microscopic invaginations called crypts feed an upward compartment of transit-amplifying cells. On migrating up, cells terminally differentiate towards secretory (goblet and enteroendocrine cells) or absorptive (enterocytes) lineages that fulfil physiological roles of the tissue. When the differentiated cells arrive at the top of the villus - villi are finger-like

\footnotetext{
${ }^{* *}$ Presented on the XX. Biological Days - Stem cells - from regenerative medicine to cancer, Pilsen, October 25-27, 2011
} 


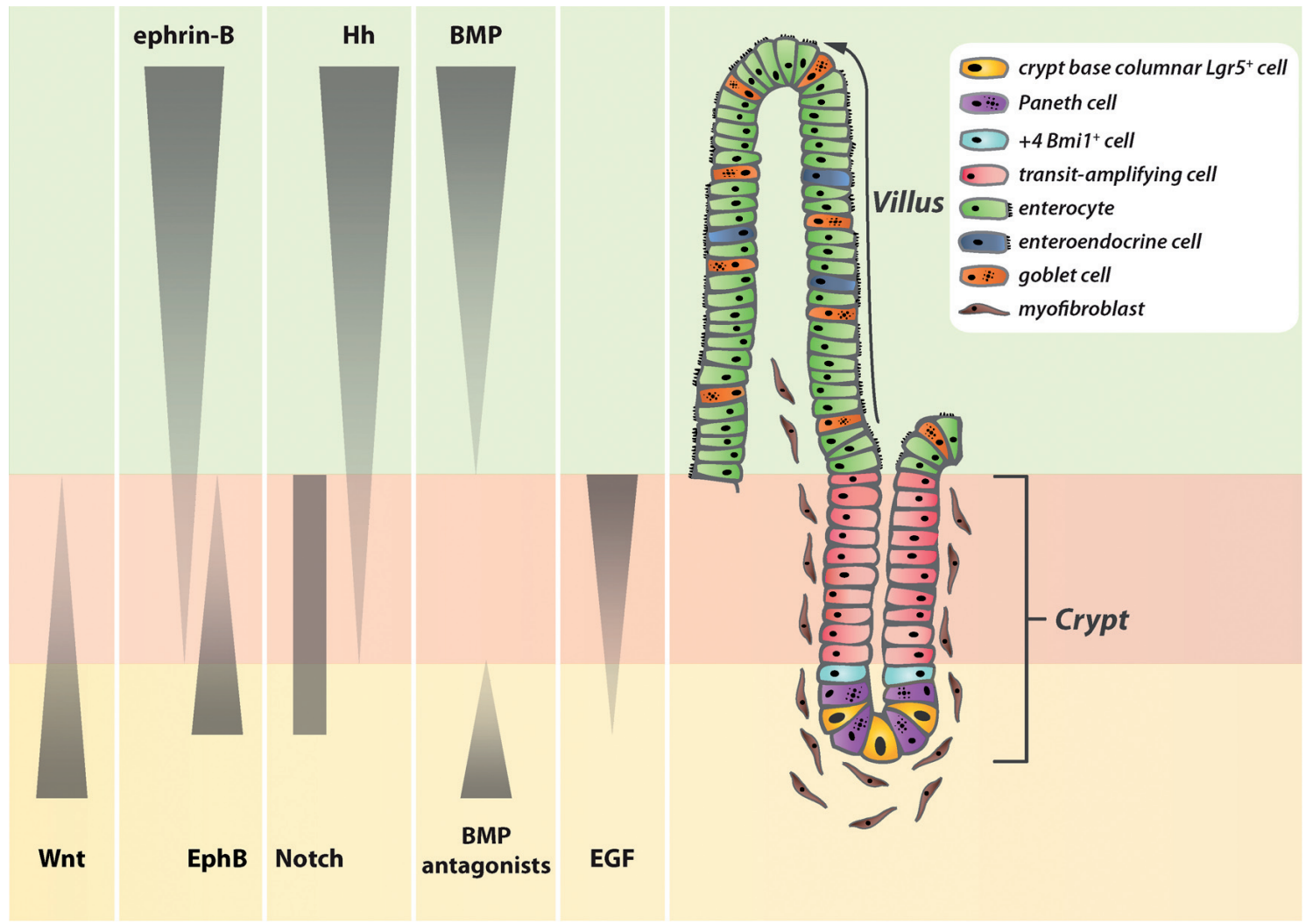

Figure 1. Architecture of the small intestine epithelium and pathways governing its fate

A population of actively cycling, crypt base columnar (CBC) stem cells positive for Lgr5 resides at the bottom of the crypt intermingled with Paneth cells. In contrast, more quiescent stem cells expressing Bmil are present above the Paneth cells at the +4 position from the crypt base. Cell divisions in the $\mathrm{CBC}$ compartment give rise to transit-amplifying (i.e. committed progenitor) cells that terminally differentiate towards all intestinal lineages as they move up the villus (arrow). Once reaching its top, the cells undergo apoptosis and are shed to the intestinal lumen. The only exceptions are long-lived postmitotic Paneth cells which stay at the bottom of the crypt. The proper homeostasis of the intestinal epithelium is regulated by an interconnected network of principal signalling pathways that govern the balance between proliferation and lineage specification. Synergism of the Wnt and Notch pathways sustains undifferentiated and proliferative stem and progenitor cells; moreover, both cascades are essential for adopting a specific lineage commitment. A descending Wnt signal generates an opposing gradient of repulsive EphB/ephrin-B interactions that facilitate spatial segregation of distinct cellular compartments within the crypt. Paracrine Hedgehog and BMP signalling in the upper part of the crypt and on the villus promote differentiation while restraining cell proliferation. The pro-differentiation activity of the BMP pathway is, at the bottom of the crypt, locally counteracted by secreted mesenchyme-derived BMP antagonists. Notably, the amplitude of mitotic signalling downstream of EGF is, at the crypt base, suppressed to restrict the expansion of the stem cell compartment.

projections of epithelium found only in the small intestine - or to the luminal surface of the large intestine, they undergo apoptosis and are shed to the intestinal lumen. Paneth cells of the small intestine are the only exception to this scheme. These antibacterial agent-producing cells stay at the crypt base where they persist for approximately three to six weeks. In addition, M-cells [9], brush cells [10] and tuft cells [11] represent further minor mucosal populations.

Two types of intestinal stem cells have been described based on their markers and location in the crypt. Fast-cycling crypt base columnar (CBC) stem cells are found interspersed among the Paneth cells and are positive for leucine-rich-repeat containing G-protein coupled receptor (Lgr) 5 [12]. The intestine also contains slowly dividing stem cells that reside several cell diameters from the bottom of the crypt. These cells express polycomb group protein Bmil and represent the reserve stem cell population $[13,14]$. The niche for the stem cells is possibly constituted by pericryptal myofibroblasts closely lining the crypt base basal lamina [15]. Recently, Sato and colleagues reported that the tissue niche for CBC cells is generated mainly by Paneth cells [16]. However, since the Lgr5-positive CBC cells retain their proliferative and clonogenic capacity even upon complete ablation of Paneth cells, the contribution of Paneth cells to the stem cell niche remains questionable [17].

The proper maintenance of epithelial architecture is controlled by various signalling pathways that regulate the balance between the opposing processes of proliferation and differentiation [18]. Importantly, the majority of these pathways is deregulated in CRC, including Wnt/ $\beta$-catenin, 
Hedgehog and Notch signalling, the ephrin type-B receptor (EphB)/ephrin-B cell communication system, the bone morphogenetic protein (BMP) signal transduction pathway and signalling downstream of the epidermal growth factor receptor [(EGFR); Figure 1]. Here, we present recent findings regarding the role of these principal pathways in both the healthy or diseased gut tissue. Moreover, particular types of CRC, both sporadic and hereditary, can be recapitulated in genetically engineered mice [19]. Employment of the mouse models brings new insights about the signalling mechanisms functioning in the gut tissue and in addition provides valuable clues for the establishment of stratification criteria for patients with CRC [20].

Wnt/ $\beta$-catenin and EphB/ephrin-B signalling. Wnt proteins are secreted ligands that bind to the Wnt receptor complex composed of a seven-span transmembrane receptor of the Frizzled (Fz) family and a lipoprotein-related co-receptor (Lrp5/6). The central feature of canonical Wnt signalling is the post-transcriptional control of $\beta$-catenin protein stability [21]. In the absence of a Wnt ligand, the intracellular level of $\beta$-catenin is kept constantly low due to the activity of its degradation complex, consisting of scaffolding proteins axis inhibition protein (Axin) and adenomatous polyposis coli $(\mathrm{Apc})$, and kinases casein kinase 1 alpha $(\mathrm{Ck} 1 \alpha)$ and glycogen synthase kinase- 3 beta (Gsk-3 $\beta$ ). The recruited $\beta$-catenin is phosphorylated and subsequently destroyed in the ubiquitinproteasome pathway. Wnt signalling leads to the membrane sequestration of Axin followed by disruption of the $\beta$-catenin degradation complex and the accumulation of the protein in the cytoplasm and nucleus. Nuclear $\beta$-catenin associates with transcription factors of the lymphoid enhancer-binding (Lef)/T-cell factor (Tcf) family (afterwards referred to as Tcfs). These high mobility group (HMG) box-containing effectors of the Wnt pathway function in an unstimulated cell as transcriptional repressors. However, since $\beta$-catenin contains a strong transactivation domain, $\mathrm{Tcf} / \beta$-catenin heterocomplexes activate transcription of specific Wnt-responsive genes such $c-M y c$ [22], Cyclin D1 [23, 24], CD44 [25] and Axin2 [26]. For a more comprehensive survey on Wnt signalling, refer to the Wnt signalling home page at http://www.stanford.edu /group/nusselab/cgi-bin/wnt/.

In the adult mouse intestine, crypt-restricted expression of Wnt3, Wnt6, Wnt9b and their cognate receptor Fz5 was observed, indicating that proper epithelial turnover is maintained by a descending gradient of Wnt signalling along the crypt-villus axis $[27,28]$. The activity of the Wnt pathway is essential for preservation of undifferentiated and proliferative stem and progenitor cells as revealed by disruption or conditional ablation of the genes encoding HMG box family member Tcf4 $[29,30,31]$ or $\beta$-catenin $[32,33]$. Importantly, sustainment of the progenitor phenotype is dependent on the direct repression of cell cycle inhibitor $p 21^{\text {Cip } 1 / \text { Waf } 1}$ which is mediated by the Tcf 4 target gene $c-M y c$ [34]. Inhibition of the pathway results in a robust G1 arrest and consequently halts cell proliferation [35]. A similar phenotype was observed upon blocking the signalling via ectopic expression of dickkopf 1 (Dkk1), a secreted Wnt inhibitor [36, 37].

The pathway controls self-renewal of CBC stem cells via activity of its responsive genes encoding the basic helix-loophelix (bHLH) transcription factor achaete-scute complex homolog 2 (Ascl2) [38] and Lgr5. Targeted deletion of either Ascl2 [38] or Lgr5 [39] leads to the elimination of CBC stem cells. In contrast to CBC cells, Bmil-positive intestinal stem cells are Wnt signalling independent [14]. Interestingly, Lgr5 and its related receptors Lgr4 and Lgr6 bind extracellular Wnt signalling agonists R-Spondins (RSpos) and association of RSpos with the receptors mediates enhancement of the Wnt signal $[39,40,41]$. The Wnt signalling pathway in CBC cells is possibly activated by the Wnt3 ligand secreted from neighbouring Paneth cells [42]. Nevertheless, as described above, CBC cells maintain their "stemness" even in the absence of Paneth cells. Therefore, the cellular source of the Wnt signal in the intestinal crypts remains unknown. Some controversies also prevail about a possible role of Ascl2 and Lgr5 in gut tumorigenesis. While Ascl2 expression in transgenic mice induced crypt hyperplasia, ectopic Ascl 2 did not promote intestinal neoplasia $[38,43]$. In addition, several research teams described elevated expression of ASCL2 or LGR5 in human sporadic cancer $[44,45,46,47]$; however, these observations have not been confirmed by parallel studies [48, 49].

Injection of human RSPO1 into mice induced a rapid onset of proliferation of crypt cells [50]. Similarly, homozygous inactivation of the $A p c$ gene in the mouse intestine drives hyperproliferation of the crypt compartments followed by formation of adenomatous intestinal polyps displaying increased levels of $\beta$-catenin [51]. In humans, germinal mutations of the APC gene are causative in development of the Familial adenomatous polyposis (FAP) syndrome, an autosomal dominant disorder characterised by multiple colorectal polyps and a variety of extraintestinal manifestations [52]. Moreover, inactivating mutations of both alleles of $A P C$ are detected in approximately one third of all sporadic CRC cases [53]. Mutations inactivating other negative regulators of Wnt signalling, AXIN1 or AXIN2, are rare and observed in CRC cases displaying microsatellite instability (MSI) [54]. Similarly to $A X I N 1 / 2$-deficient neoplasia, oncogenic mutations in the $\beta$-CATENIN gene have low frequency and are found mainly in tumors with MSI [53]. These mutations affect the regions encoding regulatory $\mathrm{N}$-terminal serine or threonine residues phosphorylated in the wild-type protein by CK1 $\alpha$ or GSK-3 $\beta$ kinases. Consequently, a mutated form of $\beta$-catenin accumulates in the affected cell and triggers aberrant Wnt signalling [55]. The oncogenic activation of $\beta$-catenin was successfully recapitulated in mice by cre-mediated "in-frame" deletion of exon 3 (encoding regulatory serines and threonines) of the $\beta$-catenin gene in the intestine $[56,57]$. All this data supports the notion that non-physiological Wnt signalling is associated with cancer development. Unexpectedly, one recent study indicated that silencing of the Wnt-responsive genes such as ASCL2, AXIN2 and LGR5 by selective promoter methylation 
identifies patients with a risk of recurrence [58]. Importantly, re-expression of these genes was associated with reduced tumor growth in vitro and in vivo. Therefore, the activity status of the selected Wnt signalling target genes can be used as one of the patient stratification criteria.

Wnt signalling is also implicated in the proper commitment and morphological maturation of the Paneth cell lineage. A homeostatic threshold of active Wnt $/ \beta$-catenin signalling is required for terminal differentiation towards the Paneth cells fate, as this is otherwise severely impaired $[27,59]$. In the lower parts of the intestinal crypts, high levels of Wnt signalling induce expression of the cell-sorting receptors EphB2 and EphB3 with concomitant transcriptional repression of their repulsive ephrin-B1 ligand [60]. As progenitor cells leave the crypt bottom, the decline in Wnt cues results in the de-repression of the repulsive ephrin-B1 ligand $[60,61]$. The decrease of Wnt signalling along the crypt-villus axis is therefore involved not only in proper epithelial turnover but also controls correct positioning of cells by opposing gradient of transmembrane EphB2/B3-ephrin-B1 signalling. Paneth cells that exclusively express EphB3 escape the upward flow and drift towards the crypt bottom [60]. The importance of EphB3 in the positioning of Paneth cells was gleaned from studies using EphB3 null mice. In the EphB3 $3^{-/}$small intestine, Paneth cells do not follow their correct migratory path but are scattered along the villi [60]. A similar phenotype was observed in $\mathrm{Fz}^{-1-}$ mice [27] or upon conditional deletion of the gene encoding ephrin-B1 ligand [62]. Paneth cells fail to correctly specify upon conditional ablation of the Wnt target genes sex determining region Y (SRY)-box 9 (Sox9) $[63,64]$ and SAM pointed domain containing the ets transcription factor (Spdef) [65]. Expectedly, aberrant Wnt signalling induces de novo production of Paneth cells $[27,59,66]$. Inappropriate expression of Paneth cell-specific genes [e.g. matrix metalloproteinase 7 (Mmp7), EphB3] was frequently observed in gastrointestinal cancer with aberrant Wnt signalling [27, 67]. Interestingly, the increased expression of EphB is often silenced during cancerous growth possibly to overcome spatial restraints imposed by surrounding healthy tissue expressing ephrin-B1 $[62,68]$. In general, abrogation of EphB-ephrin-B1 interactions in CRC coincides with acquisition of the malignant phenotype [62] and the degree of EPHB2 down regulation parallels a poor prognosis $[69,70]$.

Hedgehog signalling. The twelve-pass transmembrane proteins patched (Ptch) 1 and 2 are receptors for secreted ligands of the Hedgehog $(\mathrm{Hh})$ family which consists of three identified members in vertebrates designated as sonic hedgehog (Shh), Indian hedgehog (Ihh), and desert hedgehog (Dhh). In its "offstate", Ptch prevents the entry of an otherwise constitutively active receptor smoothened (Smo) to the primary cilium. Under these circumstances, the zinc-finger transcription factors glioma-associated oncogene (Gli) 2 and Gli3, major effectors of the Hedgehog pathway, are cleaved by proteasome into repressive forms. Conversely, upon $\mathrm{Hh}$ binding, de-repression of Smo results in a cascade of downstream events that ultimately lead to Gli-dependent transcriptional activation of Hedgehog signalling target genes (reviewed in [71]).

Hedgehog signalling in gut homeostasis mediates reciprocal cross-talk between the epithelium and the adjacent mesenchyme. Shh and Ihh ligands secreted by transit-amplifying cells interact with Ptch receptors localised on mesenchymal cells to induce Bmp production $[72,73]$. Paracrine Bmp signalling promotes enterocyte commitment and inhibits formation of additional crypts $[72,74]$. The constitutive activation of the Hedgehog pathway - upon deletion of the Ptch1 gene - leads to increased Bmp signalling with concomitant depletion of the proliferating progenitors [74]. In contrast, reduction in the levels of Hedgehog signalling enhances the Wnt pathway activity resulting in impaired intestinal differentiation and crypt hyperplasia [72, 75, 76]. Additionally, the Hedgehog pathway controls proper maintenance of intestinal smooth muscle populations $[74,76,77]$.

Several types of sporadic and hereditary cancers are dependent on Hedgehog signalling and/or carry genetic changes in the components of the Hedgehog pathway. SHH and $\mathrm{IHH}$ expression is significantly increased in a subset of human CRC and CRC-derived cell lines [78, 79, 80]; however, the contribution of the pathway to CRC is somewhat controversial [81]. In concordance with the role for Hedgehog signalling in healthy tissue, Hh proteins produced in tumor cells likely activate the signalling in the tumor-associated stroma. This was confirmed in experiments utilising human tumor xenografts. Yauch and colleagues showed that inhibition of the pathway by either small molecule inhibitors of Smo, neutralising anti-Hh antibody, or genetic ablation of the Smo gene substantially reduced size of the tumor implants growing in mice [80]. Contrary to these results, Varnat and colleagues described ligand-driven autocrine Hedgehog signalling loops promoting the growth of tumor cells [79]. Despite these rather contradictory data, inhibition of the Hedgehog pathway is considered to be promising for treatment of Hh-dependent tumors [81].

Notch signalling. The mammalian Notch family comprises four single transmembrane Notch1-4 receptors and five transmembrane Delta/Serrate/Lag2 (DSL) ligands, jagged (Jag) 1, Jag2, delta-like (Dll) 1, Dll3 and Dll4. Ligand-receptor engagement on neighbouring cells triggers a cascade of proteolytic cleavage of the Notch receptor liberating its notch intracellular domain (NICD). NICD then shuttles to the nucleus, where it binds to the recombination signal binding protein for immunoglobulin kappa J region (RBPj) core transcription factor. Heterocomplex NICD-RBPj activates expression of target genes, such as bHLH transcription repressors achaete-scute and hairy and enhancer of split (Hes) [82].

The Notch pathway governs the intestinal binary cell fate decision between the secretory versus absorptive cell lineages. Progenitor cells receiving a Notch signal are stimulated to express Hes1, which in turn antagonises the effector bHLH transcriptional factor atonal homolog 1 (Atoh1, also called Math1) [83]. Subsequent differentiation towards enterocytes is under the control of the Hes1/E74-like factor 3 (Elf3)/trans- 
forming growth factor beta (TGF $\beta$ ) signalling cascade $[84,85]$. Consistently, blocking the pathway using pharmacological inhibition of the Notch receptor-cleaving protease $\gamma$-secretase [86], genetic ablation of RBPj [86], Hes1 [83], Elf3 [87] or simultaneous deletion of both Notch1 and Notch 2 genes [88] is phenotypically associated with an excess of secretory cells at the expense of enterocytes. Production of secretory lineages from the cells expressing Notch ligands depends on the function of Atoh1, since inactivation of the Atoh1 gene results in depletion of goblet, Paneth and enteroendocrine cells [89, 90, 91]. Moreover, cell commitment to the secretory lineages is blocked in transgenic mice expressing the intestine-specific NICD protein [92]. Of note, Notch activity promotes terminal differentiation of goblet cells via suppression of zinc-finger transcription factor Krüppel-like factor 4 (Klf4) [93, 94].

Although the contribution of Paneth cells to the niche for $\mathrm{CBC}$ cells remains to be confirmed (see previous text), the involvement of Notch signalling in the maintenance of intestinal stem cells has been well-established. In the mouse, Notch 1 and Notch2 represent the predominant receptors produced on the surface of CBC cells [95], with their ligands Dll1 and Dll4 being expressed on neighbouring Paneth cells [16]. Furthermore, sustained proliferation of crypt cells is mediated through direct transcriptional repression of cyclin-dependent kinase (CDK) inhibitors $\mathrm{p} 27^{\mathrm{Kip} 1}$ and $\mathrm{p} 57^{\mathrm{Kip} 2}$ by the Notch-responsive gene Hes 1 [88]. In agreement with these data, Dll1/4 double deficient mice displayed premature differentiation of stem cells [96]. In CRC with perturbed Wnt signalling, $\beta$-catenin-driven aberrant expression of the Notch ligand JAG1 was observed, indicating synergism of both pathways. It has been proposed that while Wnt signalling enhances proliferation, the Notchdependent contribution to tumorigenesis includes a block of differentiation and promotion of vasculogenesis [97].

The BMP pathway. BMPs belong to the TGF $\beta$ superfamily of extracellular signalling molecules. Upon binding of a BMP ligand to a membrane heterocomplex of BMP type I (Bmpr1) and BMP type II (Bmpr2) receptor, the signal is further transduced through receptor-mediated phosphorylation of Smad1/5/8 transcription factors [alternatively named, mothers against decapentaplegic homolog (Madh)]. Phosphorylated Smads associate with the core mediator Smad4 and enter the nucleus to regulate expression of target genes such as the $M s x$ homeobox genes or proto-oncogene JunB [98]. Extracellular antagonists, such as noggin, follistatin or gremlin, sequester Bmp ligands, thereby abrogating their interaction with the receptors [99].

In the intestine, the BMP pathway is implicated in restraining cell proliferation. The signalling is activated in the epithelial cells by BMPs produced in the mesenchyme [15, 100]. Bmp signalling is restricted to epithelial compartments containing differentiated cells as the activity of the pathway in the crypt is locally counteracted by expression of the Bmp antagonists $[15,101,102,103]$. Inhibition of the Bmp pathway in the mouse intestine using transgenic expression of noggin [104] or conditional ablation of the Bmprla receptor [101] was associated with development of hamartomatous polyps morphologically corresponding to lesions found in the human Juvenile polyposis syndrome [101]. The formation of benign intestinal hamartomas represents an initiator event in carcinoma development in affected individuals carrying inactivating mutations in the BMPR1A or SMAD4 genes [105]. Interestingly, in sporadic $C R C$, epigenetic silencing of $B M P R 2$ or deletion of SMAD4 promotes transition from adenoma to carcinoma, i.e. a late event in the tumor progression cascade $[99,106]$. In the mouse, conditional inactivation of Bmpr2 in stromal cells of the colon initiated epithelial hyperplasia and formation of hamartomatous polyps. Strikingly, the polyps formed in these mutant animals showed increased proliferation not only of epithelial but also mesenchymal cells, especially myofibroblasts [107].

EGF signalling. Binding of EGF or related ligands to their cognate receptors, members of the ErbB/HER/Neu family of receptor tyrosine kinases, activates several major cellular prosurvival and proliferation-inducing pathways that include the Ras-Raf-mitogen activated protein kinase (MAPK) cascade, phosphatidylinositol 3-kinase (PI3K)/Akt, and phospholipase C pathways [108]. EGF signalling is required for proliferation and maintenance of the intestinal $\mathrm{CBC}$ stem cell compartments [16]; however, its output is tightly controlled by leucine-rich repeats and immunoglobulin-like domains (Lrig) 1 produced in the stem cell niche $[109,110]$.

As many as $30 \%$ of sporadic CRC cases carry mutations in the KRAS gene that compromise inactivating hydrolysis of Ras-bound GTP to GDP, thus rendering the mitogenic downstream signalling constitutively activated [53]. Oncogenic Kras is considered to be involved in later stages of CRC, where it synergises with the changes initiated by the loss of Apc $[111,112]$. This stage-specific function of Kras in CRC was supported by studies in the mouse showing that oncogenic activation of Kras induced premalignant epithelial hyperplasia [113] which, however, did not progress to malignancy [114]. Interestingly, perturbed Wnt signalling promotes stabilisation of the Ras protein and, consequently, stimulates activity of the MAPK pathway [115].

Non-physiological activation of the EGF cascade may also occur through changes affecting EGFR, PI3K, or RAS downstream effector $B R A F$ (full name: $v$-raf murine sarcoma viral oncogene homolog B1) [116]. EGFR itself can be hyperactivated by overexpression and mutations in the kinase domain or by gene amplification [117]. The p110 catalytic subunit alpha of PI3K (encoded by the PIK3CA gene) is found mutated in 15$18 \%$ of CRC [118]; however, the clinical relevance of distinct mutations found in PIK3CA remains to be elucidated [119]. Additionally, loss of phosphatase and tensin homolog (PTEN), a tumor suppressor gene encoding dual phosphatise regulating the levels of phosphatodylinositol-3,4,5-trisphosphate, is involved in the process of bowel tumorigenesis. Notably, germline mutations in PTEN underlie the Cowden syndrome, a disease characterised by development of hamartomatous polyps [120]. A phenotype similar to the Cowden syndrome 
was recapitulated in Pten heterozygous mice [121], supporting the role of PTEN in human cancer. In sporadic CRC, loss of heterozygosity (LOH) in the PTEN locus is common but presumably represents an additional "hit" during later stages of malignant progression [122]. Approximately 12-19\% of colorectal carcinomas harbour an oncogenic mutation activating kinase $B R A F[123,124]$. These mutations occur in a mutually exclusive manner with activation of KRAS [125]. Strikingly, whereas $B R A F$ changes are associated with colorectal cancers with a so-called serrated morphology displaying CpG island methylator phenotype (CIMP) or MSI, KRAS mutations are linked predominantly to tumors characterised by chromosomal instability (CIN) [126]. The "druggable" properties of EGFR led to clinical usage of EGFR antagonists, e.g. receptor-specific monoclonal antibodies cetuximab and panitumumab or small molecule tyrosine kinase inhibitors gefitinib and erlotinib [127]. Moreover, the presence of mutant KRAS or BRAF has been established as a predictive marker of "non-response" to EGFR-targeting treatment [128].

Other signalisations involved in intestinal homeostasis and CRC development. Several other cellular signalling systems have been demonstrated to regulate proper maintenance of the intestinal epithelium. Abrogation of the interaction between epithelial platelet-derived growth factor (Pdgf) ligand A with its cognate mesenchymal Pdgf receptors (Pdgfr) results in misshaping of villi and loss of the pericryptal stroma [129]. Furthermore, liver kinase B1 (Lkb1) [also known as serine/threonine kinase (Stk) 11] regulates epithelial cell polarity and metabolism [130, 131]. LKB1 acts as a tumor suppressor and its germline mutations cause the Peutz-Jeghers syndrome, a predominantly inherited disease characterised by development of gastrointestinal hamartomatous polyps [132]. The Peutz-Jeghers syndrome is phenocopied in $L k b^{+/-}$mice [133]. Interestingly, polyp development can also be initiated by a mesenchymal-specific deletion of the $L k b 1$ gene [134]. In summary, results obtained in mouse models of the Juvenile polyposis, Cowden and Peutz-Jeghers syndromes support the notion that the initiating event in the development of some CRC likely occurs in mesenchymal tissue adjacent to the epithelia.

\section{Conclusion}

A wealth of genetic studies have provided invaluable insights into the signalling networks that govern homeostasis of the gastrointestinal tissue and are at the same time "hijacked" to drive malignant conversion. A better understanding of the relationships and interconnectivity between tissue homeostatic signalling and distinct aspects of tumor initiation and progression can lead to the discovery of potential targets for therapeutic intervention. Concomitantly, mouse model systems can substantially contribute to the establishment of prognostic or predictive biomarkers that, upon translation and validation in human medicine, can be implemented to individualise anti-cancer treatment.
Acknowledgements: We thank S. Takacova and T. O'Hearn, II for critically reading the manuscript and P. Mazna for help with preparation of the figure. This work was supported by the Grant Agency of the Czech Republic (grants numbers P305/11/1780, P305/12/2347, P304/11/1252 and 204/09/H058) and the institutional grant (RVO 68378050).

\section{References}

[1] JEMAL A, SIEGEL R, XU J, WARD E Cancer statistics, 2010. CA Cancer J Clin 2010; 60, 277-300. http://dx.doi. org/10.3322/caac. 20073

[2] VOGELSTEIN B, FEARON ER, HAMILTON SR, KERN SE, PREISINGER AC et al. Genetic alterations during colorectal-tumor development. N Engl J Med 1988; 319, 525-532. http://dx.doi.org/10.1056/NEJM198809013190901

[3] LEARY RJ, KINDE I, DIEHL F, SCHMIDT K, CLOUSER C et al. Development of personalized tumor biomarkers using massively parallel sequencing. Sci Transl Med 2010; 2, 20ra14.

[4] WOOD LD, PARSONS DW, JONES S, LIN J, SJOBLOM T et al. The genomic landscapes of human breast and colorectal cancers. Science 2007; 318, 1108-1113. http://dx.doi. org $/ 10.1126 /$ science. 1145720

[5] SJOBLOM T, JONES S, WOOD LD, PARSONS DW, LIN J et al. The consensus coding sequences of human breast and colorectal cancers. Science 2006; 314, 268-274. http://dx.doi. org/10.1126/science.1133427

[6] NOUTSOU M, DUARTE AM, ANVARIAN Z, DIDENKO T, MINDE DP et al. Critical scaffolding regions of the tumor suppressor Axin 1 are natively unfolded. J Mol Biol 2011; 405, 773-786. http://dx.doi.org/10.1016/j.jmb.2010.11.013

[7] MARSHMAN E, BOOTH C, POTTEN CS The intestinal epithelial stem cell. BioEssays 2002; 24, 91-98. http://dx.doi. org/10.1002/bies. 10028

[8] GREGORIEFF A, CLEVERS H Wnt signaling in the intestinal epithelium: from endoderm to cancer. Genes Dev 2005; 19, 877-890. http://dx.doi.org/10.1101/gad.1295405

[9] MILLER H, ZHANG J, KUOLEE R, PATEL GB, CHEN W Intestinal M cells: the fallible sentinels? World J Gastroenterol 2007; 13, 1477-1486.

[10] SBARBATI A, OSCULATI F A new fate for old cells: brush cells and related elements. J Anat 2005; 206, 349-358. http://dx.doi. org/10.1111/j.1469-7580.2005.00403.x

[11] GERBE F, VAN ES JH, MAKRINI L, BRULIN B, MELLITZER G et al. Distinct ATOH1 and Neurog3 requirements define tuft cells as a new secretory cell type in the intestinal epithelium. J Cell Biol 2011; 192, 767-780. http://dx.doi.org/10.1083/jcb.201010127

[12] BARKER N, VAN ES JH, KUIPERS J, KUJALA P, VAN DEN BORN $M$ et al. Identification of stem cells in small intestine and colon by marker gene Lgr5. Nature 2007; 449, 1003-1007. http://dx.doi.org/10.1038/nature06196

[13] TIAN H, BIEHS B, WARMING S, LEONG KG, RANGELL L et al. A reserve stem cell population in small intestine renders Lgr5-positive cells dispensable. Nature 2011; 478, 255-259. http://dx.doi.org/10.1038/nature10408

[14] YAN KS, CHIA LA, LI X, OOTANI A, SU J et al. The intestinal stem cell markers Bmil and Lgr5 identify two functionally 
distinct populations. Proc Natl Acad Sci U S A 2012; 109, 466-471. http://dx.doi.org/10.1073/pnas.1118857109

[15] KOSINSKI C, LI VS, CHAN AS, ZHANG J, HO C et al. Gene expression patterns of human colon tops and basal crypts and BMP antagonists as intestinal stem cell niche factors. Proceedings of the National Academy of Sciences of the United States of America 2007; 104, 15418-15423.

[16] SATO T, VAN ES JH, SNIPPERT HJ, STANGE DE, VRIES RG et al. Paneth cells constitute the niche for Lgr5 stem cells in intestinal crypts. Nature 2011; 469, 415-418. http://dx.doi. org/10.1038/nature09637

[17] KIM TH, ESCUDERO S, SHIVDASANI RA Intact function of Lgr5 receptor-expressing intestinal stem cells in the absence of Paneth cells. Proceedings of the National Academy of Sciences of the United States of America 2012; 109, 3932-3937. http://dx.doi.org/10.1073/pnas.1113890109

[18] MOORE KA, LEMISCHKA IR Stem cells and their niches. Science 2006; 311, 1880-1885. http://dx.doi.org/10.1126/ science. 1110542

[19] TAKETO MM, EDELMANN W Mouse models of colon cancer. Gastroenterology 2009; 136, 780-798. http://dx.doi. org/10.1053/j.gastro.2008.12.049

[20] MERLOS-SUAREZ A, BARRIGA FM, JUNG P, IGLESIAS M, CESPEDES MV et al. The intestinal stem cell signature identifies colorectal cancer stem cells and predicts disease relapse. Cell Stem Cell 2011; 8, 511-524. http://dx.doi.org/10.1016/ j.stem.2011.02.020

[21] CADIGAN KM, PEIFER M Wnt signaling from development to disease: insights from model systems. Cold Spring Harb Perspect Biol 2009; 1, a002881. http://dx.doi.org/10.1101/cshperspect.a002881

[22] HE TC, SPARKS AB, RAGO C, HERMEKING H, ZAWEL L et al. Identification of c-MYC as a target of the APC pathway. Science 1998; 281, 1509-1512. http://dx.doi.org/10.1126/ science.281.5382.1509

[23] SHTUTMAN M, ZHURINSKY J, SIMCHA I, ALBANESE C, D'AMICO $\mathrm{M}$ et al. The cyclin D1 gene is a target of the beta-catenin/LEF-1 pathway. Proc Natl Acad Sci U S A 1999; 96, 5522-5527. http://dx.doi.org/10.1073/pnas.96.10.5522

[24] TETSU O, MCCORMICK F Beta-catenin regulates expression of cyclin D1 in colon carcinoma cells. Nature 1999; 398, 422-426. http://dx.doi.org/10.1038/18884

[25] WIELENGA VJ, SMITS R, KORINEK V, SMIT L, KIELMAN $\mathrm{M}$ et al. Expression of CD44 in Apc and Tcf mutant mice implies regulation by the WNT pathway. Am J Pathol 1999; 154, 515-523. http://dx.doi.org/10.1016/S0002-9440(10)65297-2

[26] LUSTIG B, JERCHOW B, SACHS M, WEILER S, PIETSCH $T$ et al. Negative feedback loop of Wnt signaling through upregulation of conductin/axin2 in colorectal and liver tumors. Mol Cell Biol 2002; 22, 1184-1193. http://dx.doi.org/10.1128/ MCB.22.4.1184-1193.2002

[27] VAN ES JH, JAY P, GREGORIEFF A, VAN GIJN ME, JONKHEER $S$ et al. Wnt signalling induces maturation of Paneth cells in intestinal crypts. Nat Cell Biol 2005; 7, 381-386. http://dx.doi.org/10.1038/ncb1240

[28] GREGORIEFF A, PINTO D, BEGTHEL H, DESTREE O, KIELMAN $\mathrm{M}$ et al. Expression pattern of Wnt signaling components in the adult intestine. Gastroenterology 2005; 129, 626-638.

[29] KORINEK V, BARKER N, MOERER P, VAN DONSELAAR E, HULS G et al. Depletion of epithelial stem-cell compartments in the small intestine of mice lacking Tcf-4. Nat Genet 1998; 19, 379-383. http://dx.doi.org/10.1038/1270

[30] VAN ES JH, HAEGEBARTH A, KUJALA P, ITZKOVITZ S, KOO BK et al. A Critical Role for the Wnt Effector Tcf4 in Adult Intestinal Homeostatic Self-Renewal. Mol Cell Biol 2012.

[31] ANGUS-HILL ML, ELBERT KM, HIDALGO J, CAPECCHI MR T-cell factor 4 functions as a tumor suppressor whose disruption modulates colon cell proliferation and tumorigenesis. Proc Natl Acad Sci U S A 2011; 108, 4914-4919. http://dx.doi. org/10.1073/pnas.1102300108

[32] FEVR T, ROBINE S, LOUVARD D, HUELSKEN J Wnt/betacatenin is essential for intestinal homeostasis and maintenance of intestinal stem cells. Molecular and cellular biology 2007; 27, 7551-7559. http://dx.doi.org/10.1128/MCB.01034-07

[33] IRELAND H, KEMP R, HOUGHTON C, HOWARD L, CLARKE AR et al. Inducible Cre-mediated control of gene expression in the murine gastrointestinal tract: effect of loss of beta-catenin. Gastroenterology 2004; 126, 1236-1246. http://dx.doi.org/10.1053/j.gastro.2004.03.020

[34] MUNCAN V, SANSOM OJ, TERTOOLEN L, PHESSE TJ, BEGTHEL $\mathrm{H}$ et al. Rapid loss of intestinal crypts upon conditional deletion of the Wnt/Tcf- 4 target gene c-Myc. Molecular and cellular biology 2006; 26, 8418-8426. http://dx.doi. org/10.1128/MCB.00821-06

[35] VAN DE WETERING M, SANCHO E, VERWEIJ C, DE LAU W, OVING I et al. The beta-catenin/TCF-4 complex imposes a crypt progenitor phenotype on colorectal cancer cells. Cell 2002; 111, 241-250. http://dx.doi.org/10.1016/ S0092-8674(02)01014-0

[36] KUHNERT F, DAVIS CR, WANG HT, CHU P, LEE M et al. Essential requirement for Wnt signaling in proliferation of adult small intestine and colon revealed by adenoviral expression of Dickkopf-1. Proc Natl Acad Sci U S A 2004; 101, 266-271. http://dx.doi.org/10.1073/pnas.2536800100

[37] PINTO D, GREGORIEFF A, BEGTHEL H, CLEVERS H Canonical Wnt signals are essential for homeostasis of the intestinal epithelium. Genes Dev 2003; 17, 1709-1713. http:// dx.doi.org/10.1101/gad.267103

[38] VAN DER FLIER LG, VAN GIJN ME, HATZIS P, KUJALA P, HAEGEBARTH A et al. Transcription factor achaete scute-like 2 controls intestinal stem cell fate. Cell 2009; 136, 903-912. http://dx.doi.org/10.1016/j.cell.2009.01.031

[39] DE LAU W, BARKER N, LOW TY, KOO BK, LI VS et al. Lgr5 homologues associate with Wnt receptors and mediate Rspondin signalling. Nature 2011; 476, 293-297. http://dx.doi. org/10.1038/nature10337

[40] CARMON KS, GONG X, LIN Q, THOMAS A, LIU Q Rspondins function as ligands of the orphan receptors LGR4 and LGR5 to regulate Wnt/beta-catenin signaling. Proc Natl Acad Sci U S A 2011; 108, 11452-11457. http://dx.doi. org/10.1073/pnas.1106083108

[41] GLINKA A, DOLDE C, KIRSCH N, HUANG YL, KAZANSKAYA $\mathrm{O}$ et al. LGR4 and LGR5 are R-spondin receptors 
mediating Wnt/beta-catenin and Wnt/PCP signalling. EMBO Rep 2011; 12, 1055-1061. http://dx.doi.org/10.1038/ embor.2011.175

[42] SATO T, VAN ES JH, SNIPPERT HJ, STANGE DE, VRIES RG et al. Paneth cells constitute the niche for Lgr5 stem cells in intestinal crypts. Nature 2010; 469, 415-418. http://dx.doi. org/10.1038/nature09637

[43] REED KR, TUNSTER SJ, YOUNG M, CARRICO A, JOHN $\mathrm{RM}$ et al. Entopic overexpression of Ascl2 does not accelerate tumorigenesis in ApcMin mice. Gut 2011.

[44] JUBB AM, CHALASANI S, FRANTZ GD, SMITS R, GRABSCH HI et al. Achaete-scute like 2 (ascl2) is a target of Wnt signalling and is upregulated in intestinal neoplasia. Oncogene 2006; 25, 3445-3457. http://dx.doi.org/10.1038/ sj.onc. 1209382

[45] SABATES-BELLVER J, VAN DER FLIER LG, DE PALO M, CATTANEO E, MAAKE C et al. Transcriptome profile of human colorectal adenomas. Molecular cancer research 2007; 5, 1263-1275. http://dx.doi.org/10.1158/1541-7786.MCR-07$\underline{0267}$

[46] VERMEULEN L, DE SOUSA EMF, VAN DER HEIJDEN M, CAMERON K, DE JONG JH et al. Wnt activity defines colon cancer stem cells and is regulated by the microenvironment. Nat Cell Biol 2010; 12, 468-476. http://dx.doi.org/10.1038/ ncb2048

[47] STANGE DE, ENGEL F, LONGERICH T, KOO BK, KOCH $\mathrm{M}$ et al. Expression of an ASCL2 related stem cell signature and IGF2 in colorectal cancer liver metastases with 11p15.5 gain. Gut 2010; 59, 1236-1244. http://dx.doi.org/10.1136/ gut.2009.195701

[48] JUBB AM, HOEFLICH KP, HAVERTY PM, WANG J, KOEPPEN H Ascl2 and 11p15.5 amplification in colorectal cancer. Gut 2011; 60, 1606-1607; author reply 1607. http://dx.doi. org/10.1136/gut.2010.231746

[49] FAN XS, WU HY, YU HP, ZHOU Q, ZHANG YF et al. Expression of Lgr5 in human colorectal carcinogenesis and its potential correlation with beta-catenin. Int J Colorectal Dis 2010; 25, 583-590. http://dx.doi.org/10.1007/s00384-010$\underline{0903-Z}$

[50] KIM KA, KAKITANI M, ZHAO J, OSHIMA T, TANG T et al. Mitogenic influence of human R-spondin1 on the intestinal epithelium. Science 2005; 309, 1256-1259. http://dx.doi. org/10.1126/science.1112521

[51] BARKER N, RIDGWAY RA, VAN ES JH, VAN DE WETERING M, BEGTHEL $\mathrm{H}$ et al. Crypt stem cells as the cells-of-origin of intestinal cancer. Nature 2009; 457, 608-611. http://dx.doi.org/10.1038/nature07602

[52] HALF E, BERCOVICH D, ROZEN P Familial adenomatous polyposis. Orphanet journal of rare diseases 2009; 4, 22. http://dx.doi.org/10.1186/1750-1172-4-22

[53] LUCHTENBORG M, WEIJENBERG MP, WARK PA, SARITAS AM, ROEMEN GM et al. Mutations in APC, CTNNB1 and $\mathrm{K}$-ras genes and expression of hMLH1 in sporadic colorectal carcinomas from the Netherlands Cohort Study. BMC cancer 2005; 5, 160. http://dx.doi.org/10.1186/1471-2407-5-160

[54] SHIMIZU Y, IKEDA S, FUJIMORI M, KODAMA S, NAKAHARA $\mathrm{M}$ et al. Frequent alterations in the Wnt signaling pathway in colorectal cancer with microsatellite instability. Genes Chromosomes Cancer 2002; 33, 73-81. http://dx.doi. org/10.1002/gcc. 1226

[55] MORIN PJ, SPARKS AB, KORINEK V, BARKER N, CLEVERS $\mathrm{H}$ et al. Activation of beta-catenin-Tcf signaling in colon cancer by mutations in beta-catenin or APC. Science 1997; 275, 1787-1790. http://dx.doi.org/10.1126/ science.275.5307.1787

[56] HARADA N, TAMAI Y, ISHIKAWA T, SAUER B, TAKAKU K et al. Intestinal polyposis in mice with a dominant stable mutation of the beta-catenin gene. Embo J 1999; 18, 5931-5942. http://dx.doi.org/10.1093/emboj/18.21.5931

[57] SANGIORGI E, CAPECCHI MR Bmil is expressed in vivo in intestinal stem cells. Nature genetics 2008; 40, 915-920. http://dx.doi.org/10.1038/ng.165

[58] DE SOUSA EMF, COLAK S, BUIKHUISEN J, KOSTER J, CAMERON K et al. Methylation of cancer-stem-cell-associated Wnt target genes predicts poor prognosis in colorectal cancer patients. Cell Stem Cell 2011; 9, 476-485. http://dx.doi. org/10.1016/j.stem.2011.10.008 PMid:22056143

[59] ANDREU P, PEIGNON G, SLOMIANNY C, TAKETO MM, COLNOT S et al. A genetic study of the role of the Wnt/betacatenin signalling in Paneth cell differentiation. Dev Biol 2008; 324, 288-296. http://dx.doi.org/10.1016/j.ydbio.2008.09.027

[60] BATLLE E, HENDERSON JT, BEGHTEL H, VAN DEN BORN MM, SANCHO E et al. Beta-catenin and TCF mediate cell positioning in the intestinal epithelium by controlling the expression of EphB/ephrinB. Cell 2002; 111, 251-263. http://dx.doi.org/10.1016/S0092-8674(02)01015-2

[61] SOLANAS G, CORTINA C, SEVILLANO M, BATLLE E Cleavage of E-cadherin by ADAM10 mediates epithelial cell sorting downstream of EphB signalling. Nat Cell Biol 2011; 13, 1100-1107. http://dx.doi.org/10.1038/ncb2298

[62] CORTINA C, PALOMO-PONCE S, IGLESIAS M, FERNANDEZ-MASIP JL, VIVANCOS A et al. EphB-ephrin-B interactions suppress colorectal cancer progression by compartmentalizing tumor cells. Nat Genet 2007; 39, 1376-1383. http://dx.doi.org/10.1038/ng.2007.11

[63] BASTIDE P, DARIDO C, PANNEQUIN J, KIST R, ROBINE S et al. Sox9 regulates cell proliferation and is required for Paneth cell differentiation in the intestinal epithelium. J Cell Biol 2007; 178, 635-648. http://dx.doi.org/10.1083/jcb.200704152

[64] MORI-AKIYAMA Y, VAN DEN BORN M, VAN ES JH, HAMILTON SR, ADAMS HP et al. SOX9 is required for the differentiation of paneth cells in the intestinal epithelium. Gastroenterology 2007; 133, 539-546. http://dx.doi. org/10.1053/j.gastro.2007.05.020

[65] GREGORIEFF A, STANGE DE, KUJALA P, BEGTHEL H, VAN DEN BORN M et al. The ets-domain transcription factor Spdef promotes maturation of goblet and paneth cells in the intestinal epithelium. Gastroenterology 2009; 137, 1333-1345 e1331-1333.

[66] GHALEB AM, MCCONNELL BB, KAESTNER KH, YANG VW Altered intestinal epithelial homeostasis in mice with intestine-specific deletion of the Kruppel-like factor 4 gene. Dev Biol 2011; 349, 310-320. http://dx.doi.org/10.1016/ j.ydbio.2010.11.001 
[67] ANDREU P, COLNOT S, GODARD C, GAD S, CHAFEY $\mathrm{P}$ et al. Crypt-restricted proliferation and commitment to the Paneth cell lineage following Apc loss in the mouse intestine. Development 2005; 132, 1443-1451. http://dx.doi. org/10.1242/dev.01700

[68] BATLLE E, BACANI J, BEGTHEL H, JONKHEER S, GREGORIEFF A et al. EphB receptor activity suppresses colorectal cancer progression. Nature 2005; 435, 1126-1130. http:// dx.doi.org/10.1038/nature03626

[69] GUO DL, ZHANG J, YUEN ST, TSUI WY, CHAN AS et al. Reduced expression of EphB2 that parallels invasion and metastasis in colorectal tumors. Carcinogenesis 2006; 27, 454-464. PMid:16272170

[70] JUBB AM, ZHONG F, BHEDDAH S, GRABSCH HI, FRANTZ GD et al. EphB2 is a prognostic factor in colorectal cancer. Clin Cancer Res 2005; 11, 5181-5187. http://dx.doi. org/10.1158/1078-0432.CCR-05-0143

[71] INGHAM PW, NAKANO Y, SEGER C Mechanisms and functions of Hedgehog signalling across the metazoa. Nat Rev Genet 2011; 12, 393-406. http://dx.doi.org/10.1038/ $\underline{\text { nrg2984 }}$

[72] MADISON BB, BRAUNSTEIN K, KUIZON E, PORTMAN $\mathrm{K}$, QIAO XT et al. Epithelial hedgehog signals pattern the intestinal crypt-villus axis. Development 2005; 132, 279-289. http://dx.doi.org/10.1242/dev.01576

[73] MAOJ, KIM BM, RAJURKAR M, SHIVDASANI RA, MCMAHON AP Hedgehog signaling controls mesenchymal growth in the developing mammalian digestive tract. Development 2010; 137, 1721-1729. http://dx.doi.org/10.1242/dev.044586

[74] VAN DOP WA, UHMANN A, WIJGERDE M, SLEDDENSLINKELS E, HEIJMANS J et al. Depletion of the colonic epithelial precursor cell compartment upon conditional activation of the hedgehog pathway. Gastroenterology 2009; 136, 2195-2203 e2191-2197.

[75] VAN DEN BRINK GR, BLEUMING SA, HARDWICK JC, SCHEPMAN BL, OFFERHAUS GJ et al. Indian Hedgehog is an antagonist of Wnt signaling in colonic epithelial cell differentiation. Nat Genet 2004; 36, 277-282. http://dx.doi. org/10.1038/ng1304

[76] ZACHARIAS WJ, MADISON BB, KRETOVICH KE, WALTON KD, RICHARDS $\mathrm{N}$ et al. Hedgehog signaling controls homeostasis of adult intestinal smooth muscle. Dev Biol 2011; 355, 152-162. http://dx.doi.org/10.1016/j.ydbio.2011.04.025

[77] KOLTERUD A, GROSSE AS, ZACHARIAS WJ, WALTON KD, KRETOVICH KE et al. Paracrine Hedgehog signaling in stomach and intestine: new roles for hedgehog in gastrointestinal patterning. Gastroenterology 2009; 137, 618-628. http://dx.doi.org/10.1053/j.gastro.2009.05.002

[78] BIAN YH, HUANG SH, YANG L, MA XL, XIE JW et al. Sonic hedgehog-Gli1 pathway in colorectal adenocarcinomas. World J Gastroenterol 2007; 13, 1659-1665.

[79] VARNAT F, DUQUET A, MALERBA M, ZBINDEN M, MAS C et al. Human colon cancer epithelial cells harbour active HEDGEHOG-GLI signalling that is essential for tumor growth, recurrence, metastasis and stem cell survival and expansion. EMBO Mol Med 2009; 1, 338-351. http://dx.doi. org/10.1002/emmm.200900039
[80] YAUCH RL, GOULD SE, SCALES SJ, TANG T, TIAN H et al. A paracrine requirement for hedgehog signalling in cancer. Nature 2008; 455, 406-410. http://dx.doi.org/10.1038/ $\underline{\text { nature } 07275}$

[81] NG JM, CURRAN T The Hedgehog's tale: developing strategies for targeting cancer. Nat Rev Cancer 2011; 11, 493-501. http://dx.doi.org/10.1038/nrc3079

[82] RANGANATHAN P, WEAVER KL, CAPOBIANCO AJ Notch signalling in solid tumors: a little bit of everything but not all the time. Nat Rev Cancer 2011; 11, 338-351. http://dx.doi. org/10.1038/nrc3035

[83] JENSEN J, PEDERSEN EE, GALANTE P, HALD J, HELLER RS et al. Control of endodermal endocrine development by Hes-1. Nat Genet 2000; 24, 36-44. http://dx.doi.org/10.1038/71657 PMid:10615124

[84] FLENTJARN, CHU PY, NG AY,JOHNSTONECN, HEATH JK et al. TGF-betaRII rescues development of small intestinal epithelial cells in Elf3-deficient mice. Gastroenterology 2007; 132, 1410-1419. http://dx.doi.org/10.1053/j.gastro.2007.02.054

[85] NG AY, WARING P, RISTEVSKI S, WANG C, WILSON T et al. Inactivation of the transcription factor Elf3 in mice results in dysmorphogenesis and altered differentiation of intestinal epithelium. Gastroenterology 2002; 122, 1455-1466. http:// dx.doi.org/10.1053/gast.2002.32990

[86] VAN ES JH, VAN GIJN ME, RICCIO O, VAN DEN BORN $\mathrm{M}$, VOOIJS $\mathrm{M}$ et al. Notch/gamma-secretase inhibition turns proliferative cells in intestinal crypts and adenomas into goblet cells. Nature 2005; 435, 959-963. http://dx.doi.org/10.1038/ nature 03659

[87] SUZUKI K, FUKUI H, KAYAHARA T, SAWADA M, SENO $\mathrm{H}$ et al. Hes1-deficient mice show precocious differentiation of Paneth cells in the small intestine. Biochem Biophys Res Commun 2005; 328, 348-352. http://dx.doi.org/10.1016/ j.bbrc.2004.12.174

[88] RICCIO O, VAN GIJN ME, BEZDEK AC, PELLEGRINET L, VAN ES JH et al. Loss of intestinal crypt progenitor cells owing to inactivation of both Notch1 and Notch2 is accompanied by derepression of CDK inhibitors p27Kip1 and p57Kip2. EMBO Rep 2008; 9, 377-383. http://dx.doi.org/10.1038/ embor.2008.7

[89] SHROYER NF, HELMRATH MA, WANG VY, ANTALFFY $B$, HENNING SJ et al. Intestine-specific ablation of mouse atonal homolog 1 (Math1) reveals a role in cellular homeostasis. Gastroenterology 2007; 132, 2478-2488. http://dx.doi. org/10.1053/j.gastro.2007.03.047

[90] VAN ES JH, DE GEEST N, VAN DE BORN M, CLEVERS H, HASSAN BA Intestinal stem cells lacking the Math1 tumor suppressor are refractory to Notch inhibitors. Nat Commun 2010; 1, 18. http://dx.doi.org/10.1038/ncomms1017

[91] YANG Q, BERMINGHAM NA, FINEGOLD MJ, ZOGHBI HY Requirement of Math1 for secretory cell lineage commitment in the mouse intestine. Science 2001; 294, 2155-2158. http://dx.doi.org/10.1126/science.1065718

[92] FRE S, HUYGHE M, MOURIKIS P, ROBINE S, LOUVARD $D$ et al. Notch signals control the fate of immature progenitor cells in the intestine. Nature 2005; 435, 964-968. http://dx.doi. org/10.1038/nature03589 
[93] GHALEB AM, AGGARWAL G, BIALKOWSKA AB, NANDAN MO, YANG VW Notch inhibits expression of the Kruppel-like factor 4 tumor suppressor in the intestinal epithelium. Mol Cancer Res 2008; 6, 1920-1927. http://dx.doi. org/10.1158/1541-7786.MCR-08-0224

[94] ZHENG H, PRITCHARD DM, YANG X, BENNETT E, LIU G et al. KLF4 gene expression is inhibited by the notch signaling pathway that controls goblet cell differentiation in mouse gastrointestinal tract. Am J Physiol Gastrointest Liver Physiol 2009; 296, G490-498. http://dx.doi.org/10.1152/ ajpgi.90393.2008

[95] FRE S, HANNEZO E, SALE S, HUYGHE M, LAFKAS D et al. Notch lineages and activity in intestinal stem cells determined by a new set of knock-in mice. PLoS One 2011; 6, e25785. http://dx.doi.org/10.1371/journal.pone.0025785

[96] PELLEGRINET L, RODILLA V, LIU Z, CHEN S, KOCH U et al. Dll1- and dll4-mediated notch signaling are required for homeostasis of intestinal stem cells. Gastroenterology 2011; 140, 1230-1240 e1231-1237.

[97] RODILLA V, VILLANUEVA A, OBRADOR-HEVIA A, ROBERT-MORENO A, FERNANDEZ-MAJADA V et al. Jagged 1 is the pathological link between Wnt and Notch pathways in colorectal cancer. Proc Natl Acad Sci U S A 2009; 106, 6315-6320. http://dx.doi.org/10.1073/ pnas.0813221106

[98] HOLLNAGEL A, OEHLMANN V, HEYMER J, RUTHER U, NORDHEIM A Id genes are direct targets of bone morphogenetic protein induction in embryonic stem cells. J Biol Chem 1999; 274, 19838-19845. http://dx.doi.org/10.1074/ jbc. 274.28 .19838

[99] HARDWICK JC, KODACH LL, OFFERHAUS GJ, VAN DEN BRINK GR Bone morphogenetic protein signalling in colorectal cancer. Nat Rev Cancer 2008; 8, 806-812. http://dx.doi. org/10.1038/nrc2467

[100] LI X, MADISON BB, ZACHARIAS W, KOLTERUD A, STATES D et al. Deconvoluting the intestine: molecular evidence for a major role of the mesenchyme in the modulation of signaling cross talk. Physiol Genomics 2007; 29, 290-301. http://dx.doi.org/10.1152/physiolgenomics.00269.2006

[101] HE XC, ZHANG J, TONG WG, TAWFIK O, ROSS J et al. BMP signaling inhibits intestinal stem cell self-renewal through suppression of Wnt-beta-catenin signaling. Nat Genet 2004; 36, 1117-1121. http://dx.doi.org/10.1038/ng1430

[102] HARDWICK JC, VAN DEN BRINK GR, BLEUMING SA, BALLESTER I, VAN DEN BRANDE JM et al. Bone morphogenetic protein 2 is expressed by, and acts upon, mature epithelial cells in the colon. Gastroenterology 2004; 126, 111-121. http://dx.doi.org/10.1053/i.gastro.2003.10.067

[103] SNEDDON JB, ZHEN HH, MONTGOMERY K, VAN DE RIJN M, TWARD AD et al. Bone morphogenetic protein antagonist gremlin 1 is widely expressed by cancer-associated stromal cells and can promote tumor cell proliferation. Proc Natl Acad Sci U S A 2006; 103, 14842-14847. http://dx.doi. org/10.1073/pnas.0606857103

[104] HARAMIS AP, BEGTHEL H, VAN DEN BORN M, VAN ES J, JONKHEER $S$ et al. De novo crypt formation and juvenile polyposis on BMP inhibition in mouse intestine.
Science 2004; 303, 1684-1686. http://dx.doi.org/10.1126/ science. 10935873

[105] HOWE JR, SAYED MG, AHMED AF, RINGOLD J, LARSENHAIDLE $J$ et al. The prevalence of MADH4 and BMPR1A mutations in juvenile polyposis and absence of BMPR2, BMPR1B, and ACVR1 mutations. J Med Genet 2004; 41, 484-491. http://dx.doi.org/10.1136/jmg.2004.018598

[106] KODACH LL, WIERCINSKA E, DE MIRANDA NF, BLEUMING SA, MUSLER AR et al. The bone morphogenetic protein pathway is inactivated in the majority of sporadic colorectal cancers. Gastroenterology 2008; 134, 1332-1341. http:// dx.doi.org/10.1053/j.gastro.2008.02.059

[107] BEPPU H, MWIZERWA ON, BEPPU Y, DATTWYLER MP, LAUWERS GY et al. Stromal inactivation of BMPRII leads to colorectal epithelial overgrowth and polyp formation. Oncogene 2008; 27, 1063-1070. http://dx.doi.org/10.1038/ sj.onc. 1210720

[108] LIEVRE A, BLONS H, LAURENT-PUIG P Oncogenic mutations as predictive factors in colorectal cancer. Oncogene 2010; 29, 3033-3043. http://dx.doi.org/10.1038/onc.2010.89

[109] WONG VW, STANGE DE, PAGE ME, BUCZACKI S, WABIK A et al. Lrig1 controls intestinal stem-cell homeostasis by negative regulation of ErbB signalling. Nat Cell Biol 2012.

[110] POWELL AE, WANG Y, LI Y, POULIN EJ, MEANS AL et al. The pan-ErbB negative regulator Lrig1 is an intestinal stem cell marker that functions as a tumor suppressor. Cell 2012; 149, 146-158. http://dx.doi.org/10.1016/j.cell.2012.02.042

[111] LUO F, BROOKS DG, YE H, HAMOUDI R, POULOGIANNIS G et al. Mutated K-ras(Asp12) promotes tumorigenesis in $\mathrm{Apc}(\mathrm{Min})$ mice more in the large than the small intestines, with synergistic effects between K-ras and Wnt pathways. Int J Exp Pathol 2009; 90, 558-574. http://dx.doi.org/10.1111/ j.1365-2613.2009.00667.x

[112] LUO F, POULOGIANNIS G, YE H, HAMOUDI R, ARENDS MJ Synergism between K-rasVal12 and mutant Apc accelerates murine large intestinal tumorigenesis. Oncol Rep 2011; $26,125-133$.

[113] TUVESON DA, SHAW AT, WILLIS NA, SILVER DP, JACKSON EL et al. Endogenous oncogenic K-ras(G12D) stimulates proliferation and widespread neoplastic and developmental defects. Cancer Cell 2004; 5, 375-387. http://dx.doi. org/10.1016/S1535-6108(04)00085-6

[114] FENG Y, BOMMER GT, ZHAO J, GREEN M, SANDS E et al. Mutant KRAS promotes hyperplasia and alters differentiation in the colon epithelium but does not expand the presumptive stem cell pool. Gastroenterology 2011; 141, 1003-1013 e1001-1010.

[115] JEONG WJ, YOON J, PARKJC, LEE SH, KADUWALS et al. Ras Stabilization Through Aberrant Activation of Wnt/beta-Catenin Signaling Promotes Intestinal Tumorigenesis. Sci Signal 2012; 5, ra30. http://dx.doi.org/10.1126/scisignal.2002242

[116] BUNNEY TD, KATAN M Phosphoinositide signalling in cancer: beyond PI3K and PTEN. Nat Rev Cancer 2010; 10, 342-352. http://dx.doi.org/10.1038/nrc2842

[117] VECCHIONE L, JACOBS B, NORMANNO N, CIARDIELLO F, TEJPAR S EGFR-targeted therapy. Exp Cell Res 2011; 317, 2765-2771. http://dx.doi.org/10.1016/j.yexcr.2011.08.021 
[118] BARAULT L, VEYRIE N, JOOSTE V, LECORRE D, CHAPUSOT $\mathrm{C}$ et al. Mutations in the RAS-MAPK, PI(3)K (phosphatidylinositol-3-OH kinase) signaling network correlate with poor survival in a population-based series of colon cancers. Int J Cancer 2008; 122, 2255-2259. http://dx.doi. org/10.1002/ijc. 23388

[119] DE ROOCK W, DE VRIENDT V, NORMANNO N, CIARDIELLO F, TEJPAR S KRAS, BRAF, PIK3CA, and PTEN mutations: implications for targeted therapies in metastatic colorectal cancer. Lancet Oncol 2011; 12, 594-603. http:// dx.doi.org/10.1016/S1470-2045(10)70209-6

[120] MERG A, HOWE JR Genetic conditions associated with intestinal juvenile polyps. Am J Med Genet C Semin Med Genet 2004; 129C, 44-55. http://dx.doi.org/10.1002/ajmg. c. 30020

[121] DI CRISTOFANO A, PESCE B, CORDON-CARDO C, PANDOLFI PP Pten is essential for embryonic development and tumor suppression. Nat Genet 1998; 19, 348-355. http:// dx.doi.org/10.1038/1235

[122] PARSONS DW, WANG TL, SAMUELS Y, BARDELLI A, CUMMINS JM et al. Colorectal cancer: mutations in a signalling pathway. Nature 2005; 436, 792. http://dx.doi. org/10.1038/436792a

[123] KROL LC, T HART NA, METHORST N, KNOL AJ, PRINSEN $\mathrm{C}$ et al. Concordance in KRAS and BRAF mutations in endoscopic biopsy samples and resection specimens of colorectal adenocarcinoma. Eur J Cancer 2012.

[124] BALSCHUN K, HAAG J, WENKE AK, VON SCHONFELS W, SCHWARZ NT et al. KRAS, NRAS, PIK3CA exon 20, and BRAF genotypes in synchronous and metachronous primary colorectal cancers diagnostic and therapeutic implications. J Mol Diagn 2011; 13, 436-445. http://dx.doi.org/10.1016/ j.jmoldx.2011.03.002

[125] PRATILAS CA, SOLIT DB Therapeutic strategies for targeting BRAF in human cancer. Rev Recent Clin Trials 2007; 2, 121-134. http://dx.doi.org/10.2174/157488707780599393

[126] ROTH AD, TEJPAR S, DELORENZI M, YAN P, FIOCCA $\mathrm{R}$ et al. Prognostic role of KRAS and BRAF in stage II and III resected colon cancer: results of the translational study on the PETACC-3, EORTC 40993, SAKK 60/00 trial. J
Clin Oncol 2010; 28, 466-474. http://dx.doi.org/10.1200/ LCO.2009.23.3452

[127] SEBASTIAN S, SETTLEMAN J, RESHKIN SJ, AZZARITI A, BELLIZZI A et al. The complexity of targeting EGFR signalling in cancer: from expression to turnover. Biochim Biophys Acta 2006; 1766, 120-139.

[128] BENVENUTIS, SARTORE-BIANCHI A, DI NICOLANTONIO F, ZANON C, MORONI M et al. Oncogenic activation of the RAS/RAF signaling pathway impairs the response of metastatic colorectal cancers to anti-epidermal growth factor receptor antibody therapies. Cancer Res 2007; 67, 2643-2648. http://dx.doi.org/10.1158/0008-5472.CAN-06-4158

[129] KARLSSON L, LINDAHL P, HEATH JK, BETSHOLTZ C Abnormal gastrointestinal development in PDGF-A and PDGFR-(alpha) deficient mice implicates a novel mesenchymal structure with putative instructive properties in villus morphogenesis. Development 2000; 127, 3457-3466.

[130] BAAS AF, KUIPERS J, VAN DER WEL NN, BATLLE E, KOERTEN HK et al. Complete polarization of single intestinal epithelial cells upon activation of LKB1 by STRAD. Cell 2004; 116, 457-466. http://dx.doi.org/10.1016/S0092$\underline{\text { 8674(04)00114-X }}$

[131] TEN KLOOSTER JP, JANSEN M, YUAN J, OORSCHOT $\mathrm{V}, \mathrm{BEGTHEL} \mathrm{H}$ et al. Mst4 and Ezrin induce brush borders downstream of the Lkb1/Strad/Mo25 polarization complex. Dev Cell 2009; 16, 551-562. http://dx.doi.org/10.1016/ j.devcel.2009.01.016

[132] HEMMINKI A, MARKIE D, TOMLINSON I, AVIZIENYTE E, ROTH S et al. A serine/threonine kinase gene defective in Peutz-Jeghers syndrome. Nature 1998; 391, 184-187. http:// dx.doi.org/10.1038/34432

[133] BARDEESY N, SINHA M, HEZEL AF, SIGNORETTI S, HATHAWAY NA et al. Loss of the Lkb1 tumor suppressor provokes intestinal polyposis but resistance to transformation. Nature 2002; 419, 162-167. http://dx.doi. org/10.1038/nature01045

[134] KATAJISTO P, VAAHTOMERI K, EKMAN N, VENTELA E, RISTIMAKI A et al. LKB1 signaling in mesenchymal cells required for suppression of gastrointestinal polyposis. Nat Genet 2008; 40, 455-459. http://dx.doi.org/10.1038/ng.98 